\title{
Assessing the risk of attack in the management of asthma: a review and proposal for revision of the current control-centred paradigm
}

\section{*John D Blakey1', Kerry Woolnough², Jodie Fellows ${ }^{2,3}$, Samantha Walker $^{4}$, Mike Thomas $^{5}$, Ian D Pavord ${ }^{6}$}

Clinical Sciences, Liverpool School of Tropical Medicine, Liverpool, UK

2 Severe and Brittle Asthma Unit, Heartlands Hospital, Birmingham, UK

${ }^{3}$ Clinical Health Psychology, Birmingham \& Solihull Mental Health Foundation Trust, Birmingham, UK

${ }^{4}$ Asthma UK, London, UK

${ }^{5}$ Centre for Academic Primary Care, University of Southampton, UK

${ }^{6}$ Institute for Lung Health, Glenfield Hospital, Leicester, UK

Received 26th November 2012; resubmitted 27th February 2013; revised 9th April 2013; accepted 13th April 2013; online 2nd July 2013

\begin{abstract}
Asthma guidelines focus on day-to-day control of symptoms. However, asthma attacks remain common. They continue to cause mortality and considerable morbidity, and are a major financial burden to the UK National Health Service (NHS) and the wider community. Asthma attacks have chronic consequences, being associated with loss of lung function and significant psychological morbidity. In this article we argue that addressing daily symptom control is only one aspect of asthma treatment, and that there should be a more explicit focus on reducing the risk of asthma attacks. Management of future risk by general practitioners is already central to other conditions such as ischaemic heart disease and chronic renal impairment. We therefore propose a revised approach that separately considers the related domains of daily control and future risk of asthma attack. We believe this approach will have advantages over the current 'stepwise' approach to asthma management. It should encourage individualised treatment, including non-pharmacological measures, and thus may lead to more efficacious and less harmful management strategies. We speculate that this type of approach has the potential to reduce morbidity and healthcare costs related to asthma attacks.

(C) 2013 Primary Care Respiratory Society UK. All rights reserved.

JD Blakey et al. Prim Care Respir J 2013; 22(3): 344-352

http://dx.doi.org/10.4104/pcrj.2013.00063
\end{abstract}

Keywords asthma attack, asthma control, risk, management, asthma guidelines

\section{Asthma attacks}

\section{Asthma attacks remain common}

Asthma is a complex syndrome with a spectrum of presentations and clinical courses. ${ }^{1.6}$ However, in all asthma subtypes and at any age $e^{7-9}$ there is the potential for a subacute or abrupt deterioration in both symptom control and objective measures of airflow obstruction. This situation is referred to as an asthma exacerbation or asthma attack. ${ }^{10}$ We prefer the term 'asthma attack' as it seems better understood by those outside medicine and more clearly conveys the potential seriousness of the episode. ${ }^{11}$ Asthma attacks are common, 12,13 accounting for almost 90,000 admissions per annum in the $\mathrm{UK}^{14}$ and many more consultations in general practice. ${ }^{15,16} \mathrm{It}$ is notable that they no longer appear to be reducing in frequency, ${ }^{17}$ and their treatment has changed little in the past 20 years.

\section{Asthma attacks have serious consequences}

Asthma attacks are associated with substantial morbidity, not only in terms of respiratory disease and general debility from critical illness but also through the adverse effects caused by medications. ${ }^{18,19}$ The abrupt decline in physical functioning and risk of serious complications during attacks results in asthma being a significant source of anxiety and panic. ${ }^{20-24}$

An underappreciated aspect of asthma attacks is that they are associated with worsening lung function. Children with a history of asthma attacks have lung function deficits compared with their

\footnotetext{
* Corresponding author: Dr John Blakey, Respiratory Medicine, Clinical Sciences Building, Aintree University Hospital, Liverpool, UK, L9 7AL. Tel: +44 (0)151 7053246 Fax: +44 (0)151 7053370 E-mail: jblakey@liverpool.ac.uk
} 
peers $^{25,26}$ that persist and often worsen into adult life. ${ }^{27,28}$ For example, of the 1,000 children enrolled into the Childhood Asthma Management Program (CAMP), one-third had had spirometric airflow obstruction when assessed at age 6-8 years, and this proportion increased to more than half by age $18 .{ }^{29}$ Early intervention with inhaled corticosteroids appears to protect against this decline. ${ }^{30,31} \mathrm{~A}$ cohort study examining the effect of severe asthma attacks on lung function in adults found that attack frequency was closely correlated with loss of lung function: the loss of lung function in individuals experiencing one asthma attack per year was equivalent to that seen in individuals who smoke 20 cigarettes per day. ${ }^{32}$ It appears that the degree of deficit is associated with airway inflammation, ${ }^{33}$ although this relationship is complex. ${ }^{34}$ Crucially, it appears that any decline associated with asthma attacks may be ameliorated with appropriate therapy. ${ }^{31,35}$ It may be that measurements other than simple spirometry will prove more informative in elucidating the relationship between lung function and airway inflammation. ${ }^{36,37}$

Asthma also continues to be a significant cause of mortality. The number of asthma-related deaths has been slower to fall than for other largely preventable causes of death: almost as many people are recorded as dying from asthma each year as from road accidents in the UK (Figure 1). Although the true number of asthma-related deaths may well be lower than official figures suggest, ${ }^{38}$ the trend in these statistics remains worrying and has led to the recent launch of a national UK review which will report soon (http://www. rcplondon.ac.uk/projects/national-review-asthma-deaths).

The frequency and potential seriousness of asthma attacks results in considerable direct healthcare costs..$^{39,40}$ In addition, there are the social and economic consequences of a temporary reduction in functioning of a usually healthy adult or of adults caring for an acutely unwell child. ${ }^{41}$

Asthma attacks therefore lead to substantial morbidity and mortality with substantial indirect and direct economic costs. Before considering how this might be addressed, we will discuss how asthma attacks relate to two commonly considered dimensions of asthma: severity and control.

Figure 1. Deaths from asthma, road accidents, and epilepsy in 2000 and 2010. Data from UK National Statistics and the Department for Transport

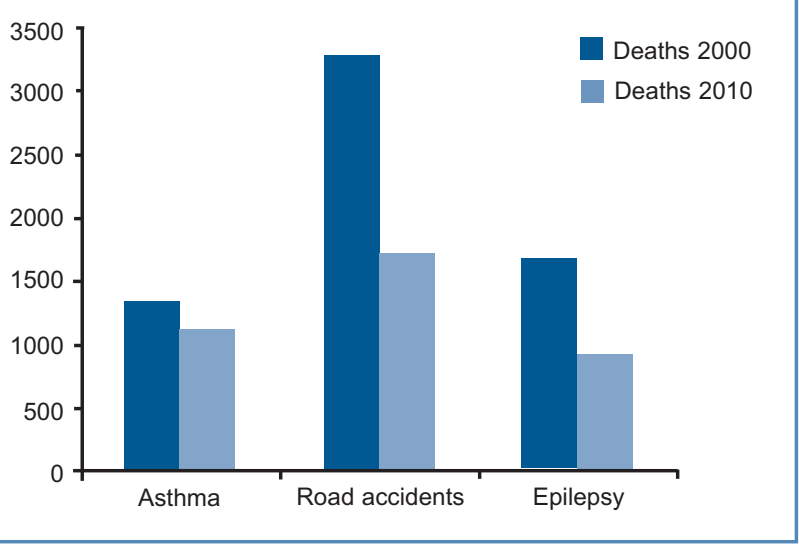

PRIMARY CARE RESPIRATORY JOURNAL www.thepcrj.org

\section{Control, severity and risk Asthma control and asthma attacks}

Several validated questionnaires of daily symptom control in asthma are in common use, such as the Asthma Control Test (ACT), ${ }^{42}$ the Asthma Control Questionnaire (ACQ), ${ }^{43}$ and the Royal College of Physicians 'Three Questions'. ${ }^{44}$ This is unsurprising as monitoring and improving daily symptom control is the focus of current international guidelines. It may seem that assessing daily control is sufficient to assess the risk of asthma attack. Indeed, poor scores on these instruments are associated with asthma attack frequency in study populations. ${ }^{45-47}$ However, their predictive value for an individual appears limited: area under receiver operator curve (ROC) values have been less than 0.7 for exacerbation outcomes. ${ }^{45}$ This poor performance stems from daily control and future risk being related but separate entities. This difference is demonstrated by serial peak expiratory flow (PEF) monitoring. The high degree of PEF variability and large bronchodilator response seen with poor daily control contrasts with reduced PEF variability (around a low value) and loss of bronchodilator response leading up to an asthma attack. ${ }^{48}$ It is also uncertain over how long daily control must be present in order to have a significant impact on future risk. Furthermore, simple control questionnaires do not put current control in the context of information that would usually be incorporated into an experienced practitioner's assessment of a patient with asthma. ${ }^{49}$ For example, retrospective analyses of large datasets have found factors such as (but not solely) smoking status, current medication, forced expiratory volume in one second $\left(\mathrm{FEV}_{1}\right)$ as a percentage of predicted, blood eosinophil count, and previous healthcare use to be predictors of poor outcomes and emergency healthcare use..$^{50-52}$ These issues lead us to consider asthma severity.

\section{Asthma severity and asthma attacks}

A significant minority of individuals with asthma have persisting daily symptoms or demonstrable airways inflammation despite compliance with potent inhaled steroids and long-acting $\beta_{2}-$ agonists. ${ }^{53,54}$ These patients have more severe asthma, but may attain significantly better control with additional asthma therapies, treatment of comorbidity and support. ${ }^{55-59}$ Equally, patients with very poorly controlled disease on suboptimal therapy may become symptom-free with the use of a single regular inhaler. ${ }^{60}$ Such findings have led to a greater clinical focus on the separation of the domains of asthma severity and control following the earlier recognition of their differing pathophysiology and expression..$^{61,62}$

Although asthma severity is associated with the risk of asthma attack, it is again not predictive: data from the European Network for Understanding Mechanisms of Severe Asthma (ENFUMOSA) found that patients with a history of near-fatal asthma in the past 5 years could not be reliably distinguished from those with mild to moderate asthma in stable conditions using common measures of asthma severity. ${ }^{63}$ The Epidemiology and Natural History of Asthma: Outcomes and Treatment Regimens (TENOR) study sought a multivariable score associated with the prospective risk of requiring hospitalisation or an emergency department visit related to asthma. Although the list of potentially informative variables in the analysis included common aspects of severe asthma definitions such as daily 
Figure 2. Schematic to illustrate the risk of asthma attack for populations of asthma patients with good, partial, and poor asthma control

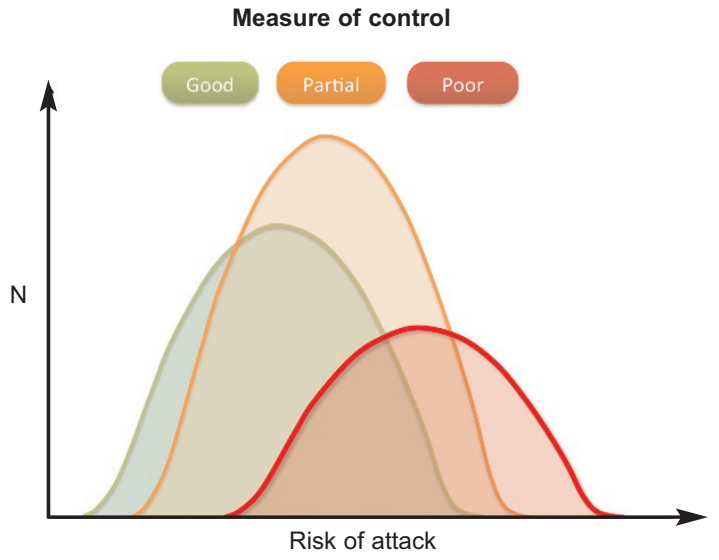

control questionnaires, inhaled or regular oral steroid use, and use of other controller medication, many such factors did not feature in the final model. ${ }^{64}$ This more inclusive approach also begins to highlight factors that are robustly associated with asthma attacks but are not captured by current questionnaires such as tobacco smoke exposure, ${ }^{65.67}$ non-concordance, ${ }^{68,69}$ socio-economic status, ${ }^{70,71}$ atopy, and upper airways disease, ${ }^{72-74}$ persistent eosinophilic airway inflammation (see above) and adiposity. 7,76

The risk of asthma attack therefore appears to be closely associated with disease severity and daily symptom control but is not fully described by them (Figure 2). Although statements and guidelines from learned institutions advocate that patient assessments should incorporate elements of current control and future risk, it is not clear how this latter aspect is accomplished. As future risk is not emphasised in these documents to the same degree as daily control, it is also unclear how commonly risk assessment is undertaken in routine practice.

\section{Phenotyping and deconstruction}

The heterogeneity of asthma of all severities has been highlighted and explored in widely read and cited papers (e.g. Haldar et al. ${ }^{9}$ ). This clinical variation is related to key underlying pathophysiological processes. ${ }^{77}$ On this background and with the evident heterogeneity in other airways disease, ${ }^{78}$ there has been a recent emphasis on the limitations of current nomenclature. A universal 'one size fits all' approach risks applying confusing or misleading labels - particularly when there is diagnostic uncertainty - and thus exposing patients to unnecessary therapy. For example, patients with a seemingly robust label of chronic obstructive pulmonary disease (COPD) may have exacerbations driven by eosinophilic inflammation, and those who do not have their recovery impaired by indiscriminate use of oral steroids. ${ }^{79,80}$ The key feature is therefore not the label of COPD but choosing appropriate treatment based on the type of inflammation occurring.

It would therefore appear that deconstructing airways diseases into their component abnormalities may be a more productive tactic than adhering to traditional labels, ${ }^{81}$ at least for those who respond suboptimally to first-line treatment. Poor daily symptom control can be driven by one or more of a number of processes which require very different treatments, such as significant airway hyperresponsiveness, heightened cough reflex, damaged airways, or dysfunctional breathing. By applying approaches such as the 'A to $E^{\prime}$ system (see Table 1), a clinician could be freed to identify which interventions will benefit the individual patient who faces them and which tests should be used for assessment and monitoring. We await with interest the outcomes of controlled assessments of such approaches.

\section{Risk of asthma attack and components of airways disease}

The relative contribution of the aforementioned pathophysiological

Table 1. The A to E of airways disease: a proposal for deconstructing complex airways disease to facilitate assessment and treatment ${ }^{81}$

\begin{tabular}{|c|c|c|c|}
\hline & Component & Clinical features & Test results \\
\hline A & $\begin{array}{l}\text { Airways hyper- } \\
\text { responsiveness }\end{array}$ & Short-term variable breathlessness and wheeze & $\begin{array}{l}\text { Methacholine challenge positive } \\
>12 \% \text { bronchodilator response } \\
>20 \% \text { PEFR variability in } 24 \text { hrs }\end{array}$ \\
\hline B & Bronchitis & $\begin{array}{l}\text { May be none } \\
\text { Subacute marked deteriorations } \\
\text { Morning productive cough }\end{array}$ & $\begin{array}{l}\text { Raised induced sputum cell count } \\
\text { Potentially high FeNO } \\
\text { Otherwise unexplained blood eosinophilia }\end{array}$ \\
\hline $\mathrm{C}$ & $\begin{array}{l}\text { Cough reflex } \\
\text { hypersensitivity }\end{array}$ & $\begin{array}{l}\text { Dry cough in relation to temperature change, } \\
\text { talking, laughing }\end{array}$ & $\begin{array}{l}\text { Excessive response to inhaled tussive stimuli } \\
\text { (e.g. capsaicin) }\end{array}$ \\
\hline $\mathrm{D}$ & Damage & Fixed limitation in exercise due to breathlessness & $\begin{array}{l}\text { Fixed airflow obstruction } \\
\text { Impaired gas transfer } \\
\text { Emphysema or bronchiectasis on CT scan }\end{array}$ \\
\hline $\mathrm{E}$ & $\begin{array}{l}\text { Extrapulmonary } \\
\text { co-morbidity }\end{array}$ & Obesity, rhinitis, vocal cord dysfunction & Dependent on nature of co-morbidity \\
\hline
\end{tabular}


processes are related to an individual's risk of an asthma attack. ${ }^{82}$ Uncontrolled eosinophilic bronchitis in asthma may lead to few daily symptoms but a high rate of asthma attack. ${ }^{9,83}$ This pattern is often seen in older men with late-onset asthma. ${ }^{9}$ Controlling such inflammation results in a significant reduction in asthma attacks. ${ }^{84}$ Similarly, people with frequent asthma symptoms may not have a great deal of inflammation. ${ }^{9,83}$ Such individuals (typically obese females, in our experience) are often unnecessarily exposed to significant quantities of corticosteroid therapy despite their low risk of a serious asthma attack; this treatment may worsen obesity and delay the introduction of a more appropriate treatment regimen. Individuals whose symptoms are driven by dysfunctional breathing rather than airways hyper-reactivity represent a more extreme disconnection between symptoms and risk. Again, the effects from oral corticosteroids and frequent $\beta_{2}$-agonist inhalation may worsen the clinical picture. The disparity between symptoms (perceived control) and objective measures of disease might therefore be an important reason why the current symptom-guided management approach fails in some patients.

The preceding observations have largely been made in a tertiary referral setting with access to induced sputum cell counts, although the principles are likely to apply to those treated in other settings. Although differential sputum cell counts are valuable, they are timeconsuming and need specialist facilities. Over-reliance on a single test such as sputum or blood eosinophilia also risks neglecting individuals at risk of attacks driven by infection or other exposures, co-morbidity, and genetic susceptibility.

Psychosocial factors require consideration when assessing the risk of asthma attack. For example, individuals who have great confidence in their own ability to manage their disease may be more likely to be non-concordant with treatment and delay seeking help when deterioration occurs. Such repressive (or 'denial coping') coping strategies ${ }^{85}$ have been found to be more common in those with near-fatal asthma attacks, ${ }^{86,87}$ as well as being associated with a greater symptom burden ${ }^{88}$ and worse lung function. ${ }^{89}$ Individual perceptions of risk of disease and treatment will also depend on circumstances, experiences, and understanding. These individual perceptions may be modified through education and shared decision-making, and these are discussed in a later section.

\section{Risk and treatment}

\section{Asthma therapies do not affect risk and control equally}

For many people with asthma, the stepwise prescription of treatment to reduce daily symptoms will be appropriate to reduce their risk of attacks. However, for the significant proportion of individuals who have discordant daily symptoms and future risk, this will not be the case: as noted, it may result in excessive therapy for those with frequent symptoms and a low risk of asthma attack, and inadequate intervention for those with fewer symptoms but who are at higher risk. The heterogeneity in clinical asthma would be a lesser issue if available interventions had an equal effect on daily symptoms and risk of acute deterioration. Under those circumstances, the current straightforward stepwise approach would be valid for almost all patients. ${ }^{90}$
Available treatments for asthma are, however, unequal in their benefit. Xanthines, for example, improve daily symptoms but do not affect the risk of an asthma attack. ${ }^{91}$ When high-dose inhaled steroids are compared with lower dose steroids/long-acting $\beta_{2}$ agonist combination therapy, the former leads to a greater reduction in asthma attacks whereas the latter has more effect on symptom scores. ${ }^{92}$ This discrepancy in effect is also apparent for newer and more costly therapies such as laminar airflow units for severe atopic asthma, ${ }^{93}$ bronchial thermoplasty for persistent airways hyperresponsiveness, ${ }^{94}$ and monoclonal antibody therapy for persistent eosinophilic inflammation. ${ }^{95}$ This latter therapy is a key example of the need to consider risk and control separately: mepolizumab (antiIL-5) was found to be ineffective in initial studies ${ }^{96}$ including people with asthma selected by (commonly applied) criteria of symptoms and bronchial hyper-reactivity. It has subsequently been shown to halve the risk of an asthma attack in individuals who are at high risk, as reflected by eosinophilic inflammation, fixed airflow obstruction, and multiple previous asthma attacks. ${ }^{95,97,98}$ Strikingly, the beneficial effects of treatment appear to be least in patients with a large acute bronchodilator response.

It is widely accepted that high-cost specialist interventions such as those mentioned above require a fuller assessment of an individual's asthma in a tertiary referral centre. This should avoid the temptation to try the next new therapy for an individual with difficult asthma and give the greatest opportunity for these interventions to prove successful and financially sustainable. However, we should not overlook the need for appropriate assessment before commencing more commonplace therapies: treatments such as inhaled corticosteroids, $^{99}$ long-acting $\beta_{2}$-agonists, ${ }^{100}$ xanthines, ${ }^{91}$ and potentially long-acting anticholinergics ${ }^{101}$ may carry a risk of significant adverse events. Some of these common therapies are also costly; for example, they account for greater healthcare expenditure than admissions, even in severe asthma. ${ }^{102}$ Drug costs are also inflated as clinicians are slow to reduce or withdraw drugs that have equivocal additional benefit. ${ }^{103}$ These costs are increasingly important in the UK NHS and are a major barrier to delivering care in developing countries. The number of long-acting bronchodilators and combination products on the horizon is likely to further complicate this picture. ${ }^{104-107}$

\section{The stepwise approach focuses on drug treatment}

The focus on treatment 'steps' in guidelines draws the user into escalating drug therapy for asthma symptoms. The resultant narrow approach may distract from other informative sections and the major benefits that can be gained from interventions such as education, weight loss and exercise, and smoking cessation programmes. In particular, stepwise management does not readily accommodate interventions requiring multidisciplinary expertise rather than a prescription. We acknowledge that aspects of asthma management such as concordance reviews with pharmacists or specialist nurses, dysfunctional breathing treatment from physiotherapists, clinical psychology input, and speech therapy assessment of vocal cord dysfunction are contained within guidance but we contend that they are not sufficiently emphasised or contextualised. The effect of 


\begin{tabular}{|c|c|c|}
\hline Intervention & Daily control & Risk reduction \\
\hline Long-acting beta-agonists (alone) & ++ & - \\
\hline Anticholinergics & ++ & + \\
\hline Corticosteroids & + & ++ \\
\hline Montelukast & + & + \\
\hline Theophylline & + & 0 \\
\hline Weight loss & ++ & + \\
\hline Concordance review & + & ++ \\
\hline Smoking cessation programme & ++ & ++ \\
\hline Physiotherapy review & ++ & 0 \\
\hline Bronchial thermoplasty & ++ & + \\
\hline Mepolizumab & 0 & ++ \\
\hline
\end{tabular}

therapeutic interventions on asthma control and risk of attack is summarised in Table 2. Engaging with the various perspectives of those involved in a multidisciplinary team also affords the opportunity to better assess patient attitudes and perceptions. ${ }^{108}$ This information enables healthcare providers to challenge the assumptions of a stepwise model such as consistency and accuracy in the patient's history, a clear understanding by the patient of the treatment intended, that treatment is taken as intended, and that all patients wish to obtain the best level of health possible. We would recommend that costly treatments or those with potentially serious adverse effects are only commenced after a multidisciplinary team review.

\section{Assessing both risk and control}

We have discussed the importance of risk as an additional consideration to daily control, and of the unequal effects of available interventions on these dimensions. It would therefore be helpful to have a simple way of assessing risk in an individual with asthma. Pilot studies suggest that the creation of such a simple risk assessment score is feasible. ${ }^{109}$ The tens of thousands of completions of the Asthma UK 'triple A' (Avoiding Asthma Attacks) test suggest that such scores may successfully engage users, ${ }^{110}$ and feedback from this test suggests it could effect favourable behavioural change. Research in this area is ongoing, ${ }^{111}$ and it is likely that risk assessment scores (with and without biomarker measurement) will be forthcoming in the near future. Explicit risk assessment could be the missing piece that has the potential to facilitate more effective treatment, which could also be cheaper if inappropriate treatment is reduced.

We believe that future asthma guidelines should consider including explicit assessments of risk and control rather than simply discussing factors related to the risk of attack. These assessments could then inform appropriate interventions. An example of a 'coordinates' system is shown in Figure 3. Under such a scheme, risk and control are assessed independently. Interventions for risk and control dimensions are then augmented or reduced along the relevant axes. In Figure 3, patient $A$ has poor control but few risk factors. Use of this new approach increases the likelihood of gaining control but does not expose the patient to unnecessary parenteral steroids as would be the case following existing guidelines. In patient $B$ the risk of severe attack is addressed, which would otherwise have been overlooked. Patient $C$ has treatment tailored to his/her specific risk factor. We acknowledge that all patients should have their

Figure 3. (A) An example of the proposed coordinates system to inform asthma management. Ongoing poor daily control results in escalation along the $y$ axis and ongoing risk of severe asthma attack leads to escalation along the $x$ axis. $L A A C=$ long-acting anticholinergic, $L A B A=$ long-acting $\beta_{2}$-agonist, SABA=short-acting $\beta_{2}$-agonist, ICS=inhaled corticosteroid. Phenotype-specific anti-inflammatory relates to oral treatment (e.g. prednisolone or macrolide). The letters on the chart relate to example patients and are discussed in the text and panel (B). (B) Treatment received by example patients A, B, and C under existing and proposed guideline structures. Patient identifying letters relate to panel (A). Smoking cessation advice is not explicitly included above but is evidently a key aspect of management

A

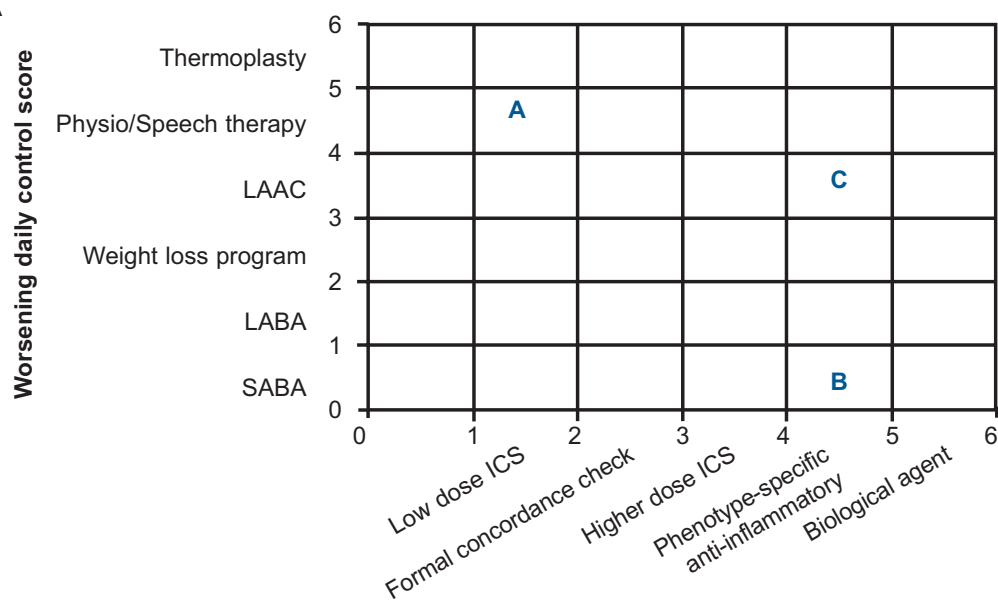

B

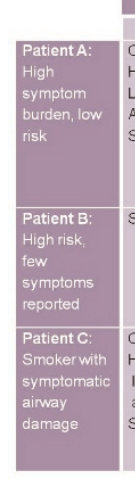

Increasing risk of attack score 
Figure 4. Example of communication following an asthma risk assessment. This approach has the potential to improve understanding of the rationale for an asthma treatment, facilitate shared decision-making, and may improve concordance

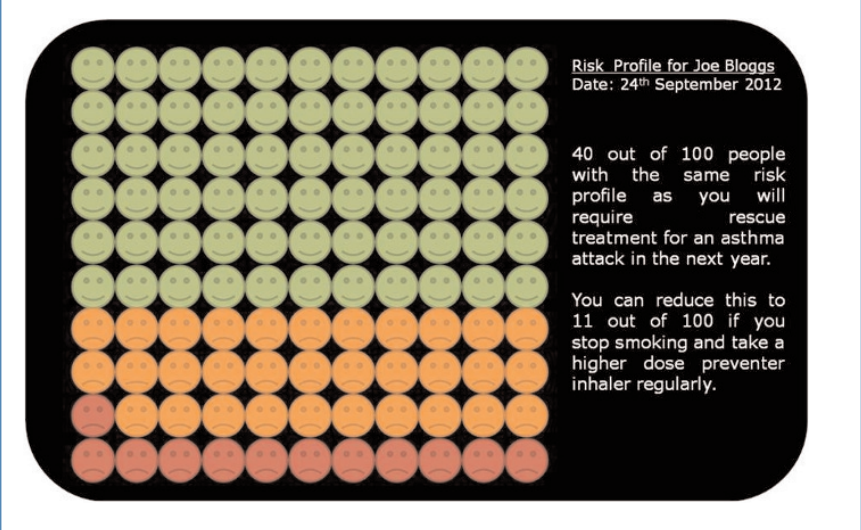

inhaler technique checked with all the devices they use, ${ }^{112}$ and suggest that the responsibility for this assessment should be explicit in local guidelines.

\section{Shared decision-making about risk}

The proposed approach has an additional advantage: by artificially separating the domains of control and risk it can become more straightforward to discuss treatment changes with patients. People with asthma can decide whether a gain in daily control is worth the potential burden of additional medications if no reduction in risk is to be expected. Similarly, by explicitly addressing risk, individuals with asthma can make informed decisions on lifestyle choices and escalation of treatment. Their current risk and the effect of an intervention can be made explicit to assist in the shared decision-making process (see example in Figure 4), ${ }^{113,114}$ as occurs in other areas of medicine. ${ }^{115}$ Giving information like this has the potential to influence for the better a patient's health-related choices ${ }^{116}$ and may improve health literacy. Collaborative discussion around risk and symptoms management to aid informed decision-making is consistent with motivational interviewing, an approach shown to improve concordance in asthma. ${ }^{17,118} \mathrm{An}$ explicit consideration of risk may also improve the engagement of some groups with 'preventer' treatment (e.g. adolescents appreciating the risk of being unwell for examinations or sporting commitments).

\section{Conclusions}

Asthma attacks matter to people with asthma, healthcare professionals, and budget holders. Identifying those at risk of an asthma attack is therefore important. The focus of current treatment guidelines on a universal stepwise approach driven by daily asthma control is of limited efficacy, can expose patients to unnecessary risk, and has the potential to neglect nonpharmacological interventions. In this article we argue that a more explicit separation of asthma control and risk is consistent with pathophysiological processes and will lead to more appropriate clinical decisions and treatments for both of these important related domains. We acknowledge that our understanding of the factors contributing to the risk of asthma attack is far from complete, and that our suggestion for a revision to management guidance is at an early stage. However, similar strategies have proved successful in other conditions in general practice, such as managing the risk of a future myocardial infarction rather than simply current angina symptoms. When such an approach is refined, it has the potential to begin to reduce morbidity both from asthma and from inappropriate treatments, may increase patient engagement and concordance, and could lead to considerable financial savings.

\section{Handling editor Björn Ställberg}

Acknowledgements The authors are most grateful for the instructive comments of Professor D Price in discussions leading up to the writing of this article.

Conflicts of interest The authors declare that they have no conflicts of interest in relation to this article. MT is an Associate editor of the PCRJ, but was not involved in the editorial review of, nor the decision to publish, this article.

Contributorship DP, MT, SW, and JDB contributed to the conception of the article. The article was drafted by JDB, KW and JF. All authors contributed to the critical appraisal and revision of the article.

Funding This article was written without specific funding

\section{References}

1. Lotvall J, Akdis CA, Bacharier LB, et al. Asthma endotypes: a new approach to classification of disease entities within the asthma syndrome. J Allergy Clin Immunol 2011;127(2):355-60. http://dx.doi.org/10.1016/j.jaci.2010.11.037

2. Gibson PG, McDonald VM, Marks GB. Asthma in older adults. Lancet 2010;376(9743):803-13. http://dx.doi.org/10.1016/S0140-6736(10)61087-2

3. Wang $F, H e X Y$, Baines $\mathrm{KJ}$, et al. Different inflammatory phenotypes in adults and children with acute asthma. Eur Respir J 2011;38(3):567-74.

http://dx.doi.org/10.1183/09031936.00170110

4. Szczeklik A, Nizankowska E, Duplaga M. Natural history of aspirin-induced asthma. AIANE Investigators. European Network on Aspirin-Induced Asthma. Eur Respir $J$ 2000;16(3):432-6. http://dx.doi.org/10.1034/j.1399-3003.2000.016003432.x

5. Strachan DP, Butland BK, Anderson HR. Incidence and prognosis of asthma and wheezing illness from early childhood to age 33 in a national British cohort. BMJ 1996;312(7040):1195-9. http://dx.doi.org/10.1136/bmj.312.7040.1195

6. Simpson CR, Sheikh A. Trends in the epidemiology of asthma in England: a national study of 333,294 patients. J $R$ Soc Med 2010;103(3):98-106. http://dx.doi.org/10.1258/jrsm.2009.090348

7. Tsai $C L$, Lee $W Y$, Hanania NA, Camargo CA, Jr. Age-related differences in clinical outcomes for acute asthma in the United States, 2006-2008. J Allergy Clin Immunol 2012;129(5):1252-8 e1

8. Bateman ED, Reddel HK, Eriksson G, et al. Overall asthma control: the relationship between current control and future risk. J Allergy Clin Immunol 2010;125(3):600-08, 8 e1-8 e6.

9. Haldar P, Pavord ID, Shaw DE, et al. Cluster analysis and clinical asthma phenotypes. Am J Respir Crit Care Med 2008;178(3):218-24. http://dx.doi.org/10.1164/rccm.200711-17540C

10. Bousquet J, Mantzouranis E, Cruz AA, et al. Uniform definition of asthma severity, control, and exacerbations: document presented for the World Health Organization Consultation on Severe Asthma. J Allergy Clin Immunol 2010;126(5):926-38. http://dx.doi.org/10.1016/j.jaci.2010.07.019

11. Fitzgerald JM. Targeting lung attacks. Thorax 2011;66(5):365-6 http://dx.doi.org/10.1136/thx.2010.156760

12. Anderson HR, Gupta R, Strachan DP, Limb ES. 50 years of asthma: UK trends from 1955 to 2004. Thorax 2007;62(1):85-90. http://dx.doi.org/10.1136/thx.2006.066407

13. Moorman JE, Rudd RA, Johnson CA, et al. National surveillance for asthma: United States, 1980-2004. MMWR CDC Surveill Summ 2007;56(SS08):18-54.

14. The NHS Information Centre. Inpatient statistics, 2010-11. 2012. Available from: http://www.hesonline.nhs.uk/Ease/servlet/ContentServer?sitelD=1937\&categorylD=202. 
15. Price D, Haughney J, Sims E, et al. Effectiveness of inhaler types for real-world asthma management: retrospective observational study using the GPRD. J Asthma Allergy 2011;4:37-47.

16. Tata $\amalg$, West J, Harrison T, Farrington P, Smith C, Hubbard R. Does influenza vaccination increase consultations, corticosteroid prescriptions, or exacerbations in subjects with asthma or chronic obstructive pulmonary disease? Thorax 2003;58(10):835-9. http://dx.doi.org/10.1136/thorax.58.10.835

17. Turner S, Thomas M, von Ziegenweidt J, Price D. Prescribing trends in asthma: a longitudinal observational study. Arch Dis Child 2009;94(1):16-22. http://dx.doi.org/10.1136/adc.2008.140681

18. Mori H, Tanaka H, Ohno $Y$, et al. Effect of intermittent systemic corticosteroid on bone metabolism in bronchial asthma patients. J Asthma 2009;46(2):142-6. http://dx.doi.org/10.1080/02770900802492095

19. Cumming RG, Mitchell P. Inhaled corticosteroids and cataract: prevalence, prevention and management. Drug Saf 1999;20(1):77-84 http://dx.doi.org/10.2165/00002018-199920010-00007

20. Thomas M, Bruton A, Moffat M, Cleland J. Asthma and psychological dysfunction. Prim Care Respir J 2011;20(3):250-6. http://dx.doi.org/10.4104/pcrj.2011.00058

21. Asthma UK. Fighting for Breath. London: Asthma UK, 2010.

22. Hasler G, Gergen PJ, Kleinbaum DG, et al. Asthma and panic in young adults: a 20year prospective community study. Am J Respir Crit Care Med 2005;171(11):122430. http://dx.doi.org/10.1164/rccm.200412-16690C

23. Weiser EB. The prevalence of anxiety disorders among adults with asthma: a metaanalytic review. J Clin Psychol Med Settings 2007;14(4):297-307. http://dx.doi.org/10.1007/s10880-007-9087-2

24. Greaves CJ, Eiser C, Seamark D, Halpin DM. Attack context: an important mediator of the relationship between psychological status and asthma outcomes. Thorax 2002;57(3):217-21. http://dx.doi.org/10.1136/thorax.57.3.217

25. Sears MR, Greene JM, Willan AR, et al. A longitudinal, population-based, cohort study of childhood asthma followed to adulthood. $N$ Engl J Med 2003;349(15):1414-22. http://dx.doi.org/10.1056/NEJMoa022363

26. Oswald $H$, Phelan PD, Lanigan A, et al. Childhood asthma and lung function in midadult life. Pediatr Pulmonol 1997;23(1):14-20. http://dx.doi.org/10.1002/(SICI)10990496(199701)23:1<14::AID-PPUL2>3.0.CO;2-P

27. James AL, Palmer LJ, Kicic $E$, et al. Decline in lung function in the Busselton Health Study: the effects of asthma and cigarette smoking. Am J Respir Crit Care Med 2005;171(2):109-14. http://dx.doi.org/10.1164/rccm.200402-2300C

28. Lange P, Parner J, Vestbo J, Schnohr P, Jensen G. A 15-year follow-up study of ventilatory function in adults with asthma. N Engl J Med 1998;339(17):1194-200. http://dx.doi.org/10.1056/NEJM199810223391703

29. Strunk RC, Weiss ST, Yates KP, Tonascia J, Zeiger RS, Szefler SJ. Mild to moderate asthma affects lung growth in children and adolescents. J Allergy Clin Immunol 2006;118(5):1040-7. http://dx.doi.org/10.1016/j.jaci.2006.07.053

30. Selroos $\mathrm{O}$, Pietinalho $A$, Lofroos $A B$, Riska $H$. Effect of early vs late intervention with inhaled corticosteroids in asthma. Chest 1995;108(5):1228-34 http://dx.doi.org/10.1378/chest.108.5.1228

31. Haahtela $T$, Jarvinen $M$, Kava $T$, et al. Comparison of a beta 2-agonist, terbutaline, with an inhaled corticosteroid, budesonide, in newly detected asthma. N Engl J Med 1991;325(6):388-92. http://dx.doi.org/10.1056/NEJM199108083250603

32. Bai TR, Vonk JM, Postma DS, Boezen HM. Severe exacerbations predict excess lung function decline in asthma. Eur Respir J 2007;30(3):452-6. http://dx.doi.org/10.1183/09031936.00165106

33. van Veen $I H$, Ten Brinke A, Sterk PJ, et al. Exhaled nitric oxide predicts lung function decline in difficult-to-treat asthma. Eur Respir J 2008;32(2):344-9. http://dx.doi.org/10.1183/09031936.00135907

34. Rossi E, Scano G. Association of sputum parameters with clinical and functional measurements in asthma. Thorax 2000;55:235-8 http://dx.doi.org/10.1136/thorax.55.3.235

35. O'Byrne PM, Pedersen S, Lamm CJ, Tan WC, Busse WW. Severe exacerbations and decline in lung function in asthma. Am J Respir Crit Care Med 2009;179(1):19-24. http://dx.doi.org/10.1164/rccm.200807-11260C

36. Gonem S, Umar I, Burke D, et al. Airway impedance entropy and exacerbations in severe asthma. Eur Respir J 2012;40(5):1156-63. http://dx.doi.org/10.1183/09031936.00228611

37. Shi Y, Aledia AS, Galant SP, George SC. Peripheral airway impairment measured by oscillometry predicts loss of asthma control in children. J Allergy Clin Immunol
2013;131(3):718-23. http://dx.doi.org/10.1016/j.jaci.2012.09.022

38. Harrison B, Stephenson P, Mohan G, Nasser S. An ongoing Confidential Enquiry into asthma deaths in the Eastern Region of the UK, 2001-2003. Prim Care Respir $J$ 2005;14(6):303-13. http://dx.doi.org/10.1016/j.pcrj.2005.08.004

39. Weiss KB, Sullivan SD, Lyttle CS. Trends in the cost of illness for asthma in the United States, 1985-1994. J Allergy Clin Immunol 2000;106(3):493-9.

http://dx.doi.org/10.1067/mai.2000.109426

40. Kamble S, Bharmal M. Incremental direct expenditure of treating asthma in the United States. J Asthma 2009;46(1):73-80. http://dx.doi.org/10.1080/02770900802503107

41. Bahadori K, Doyle-Waters MM, Marra C, et al. Economic burden of asthma: a systematic review. BMC Pulm Med 2009;9:24 http://dx.doi.org/10.1186/1471-2466-9-24

42. Nathan RA, Sorkness CA, Kosinski M, et al. Development of the asthma control test: a survey for assessing asthma control. J Allergy Clin Immunol 2004;113(1):59-65. http://dx.doi.org/10.1016/j.jaci.2003.09.008

43. Juniper EF, O'Byrne PM, Guyatt GH, Ferrie PJ, King DR. Development and validation of a questionnaire to measure asthma control. Eur Respir J 1999;14(4):902-07. http://dx.doi.org/10.1034/j.1399-3003.1999.14d29.x

44. Thomas M, Gruffydd-Jones K, Stonham C, Ward S, Macfarlane TV. Assessing asthma control in routine clinical practice: use of the Royal College of Physicians ' 3 questions'. Prim Care Respir J 2009;18(2):83-8. http://dx.doi.org/10.3132/pcrj.2008.00045

45. Sato R, Tomita $\mathrm{K}$, Sano $\mathrm{H}$, et al. The strategy for predicting future exacerbation of asthma using a combination of the Asthma Control Test and lung function test. $J$ Asthma 2009;46(7):677-82. http://dx.doi.org/10.1080/02770900902972160

46. Meltzer EO, Busse WW, Wenzel SE, et al. Use of the Asthma Control Questionnaire to predict future risk of asthma exacerbation. I Allergy Clin Immunol 2011;127(1):167-72. http://dx.doi.org/10.1016/j.jaci.2010.08.042

47. Peters D, Chen C, Markson LE, Allen-Ramey FC, Vollmer WM. Using an asthma control questionnaire and administrative data to predict health-care utilization. Chest 2006;129(4):918-24. http://dx.doi.org/10.1378/chest.129.4.918

48. Reddel H, Ware S, Marks G, Salome C, Jenkins C, Woolcock A. Differences between asthma exacerbations and poor asthma control. Lancet 1999;353(9150):364-9. http://dx.doi.org/10.1016/S0140-6736(98)06128-5

49. Lundback B, Dahl R. Assessment of asthma control and its impact on optimal treatment strategy. Allergy 2007;62(6):611-19. http://dx.doi.org/10.1111/j.1398-9995.2007.01399.x

50. Schatz M, Zeiger RS, Yang SJ, et al. Relationship of asthma control to asthma exacerbations using surrogate markers within a managed care database. Am J Manag Care 2010;16(5):327-33.

51. Osborne ML, Pedula KL, O'Hollaren M, et al. Assessing future need for acute care in adult asthmatics: the Profile of Asthma Risk Study: a prospective health maintenance organization-based study. Chest 2007;132(4):1151-61. http://dx.doi.org/10.1378/chest.05-3084

52. Kitch $B T$, Paltiel $A D$, Kuntz KM, et al. A single measure of FEV1 is associated with risk of asthma attacks in long-term follow-up. Chest 2004;126(6):1875-82. http://dx.doi.org/10.1378/chest.126.6.1875

53. Heaney LG, Brightling CE, Menzies-Gow A, Stevenson M, Niven RM. Refractory asthma in the UK: cross-sectional findings from a UK multicentre registry. Thorax 2010;65(9):787-94. http://dx.doi.org/10.1136/thx.2010.137414

54. Wenzel S. Characteristics, definition and phenotypes of severe asthma. In: Chung KF, Bel E, Wenzel S, eds. ERS Monograph: Difficult-to-Treat Severe Asthma. 51: European Respiratory Society, 2011.

55. Walker S, Monteil M, Phelan K, Lasserson TJ, Walters EH. Anti-lgE for chronic asthma in adults and children. Cochrane Database Syst Rev 2006;(2):CD003559.

56. Kerstjens HA, Engel M, Dahl R, et al. Tiotropium in asthma poorly controlled with standard combination therapy. N Engl J Med 2012;367(13):1198-207. http://dx.doi.org/10.1056/NEJMoa1208606

57. Low K, Lau KK, Holmes P, et al. Abnormal vocal cord function in difficult-to-treat asthma. Am J Respir Crit Care Med 2011;184(1):50-6.

http://dx.doi.org/10.1164/rccm.201010-16040C

58. Castro M, Zimmermann NA, Crocker S, Bradley J, Leven C, Schechtman KB. Asthma intervention program prevents readmissions in high healthcare users. Am J Respir Crit Care Med 2003;168(9):1095-9. http://dx.doi.org/10.1164/rccm.200208-8770C

59. Souza-Machado C, Souza-Machado A, Franco R, et al. Rapid reduction in hospitalisations after an intervention to manage severe asthma. Eur Respir $J$ 
2010;35(3):515-21. http://dx.doi.org/10.1183/09031936.00101009

60. Bateman ED, Boushey HA, Bousquet J, et al. Can guideline-defined asthma control be achieved? The Gaining Optimal Asthma ControL study. Am J Respir Crit Care Med 2004;170(8):836-44. http://dx.doi.org/10.1164/rccm.200401-0330C

61. Blakey JD, Wardlaw AJ. What is severe asthma? Clin Exp Allergy 2012;42(5):617-24. http://dx.doi.org/10.1111/j.1365-2222.2012.03962.x

62. Bel EH, Sousa A, Fleming $L$, et al. Diagnosis and definition of severe refractory asthma: an international consensus statement from the Innovative Medicine Initiative (IMI). Thorax 2011;66(10):910-17. http://dx.doi.org/10.1136/thx.2010.153643

63. Romagnoli M, Caramori G, Braccioni $F$, et al. Near-fatal asthma phenotype in the ENFUMOSA cohort. Clin Exp Allergy 2007;37(4):552-7. http://dx.doi.org/10.1111/j.1365-2222.2007.02683.x

64. Miller MK, Lee JH, Blanc PD, et al. TENOR risk score predicts healthcare in adults with severe or difficult-to-treat asthma. Eur Respir J 2006;28(6):1145-55. http://dx.doi.org/10.1183/09031936.06.00145105

65. Chilmonczyk BA, Salmun LM, Megathlin KN, et al. Association between exposure to environmental tobacco smoke and exacerbations of asthma in children. $N$ Eng/ J Med 1993;328(23):1665-9. http://dx.doi.org/10.1056/NEJM199306103282303

66. Comhair SA, Gaston BM, Ricci KS, et al. Detrimental effects of environmental tobacco smoke in relation to asthma severity. PLoS One 2011;6(5):e18574. http://dx.doi.org/10.1371/journal.pone.0018574

67. Eisner MD, Klein J, Hammond SK, Koren G, Lactao G, Iribarren C. Directly measured second hand smoke exposure and asthma health outcomes. Thorax 2005;60(10):814-21. http://dx.doi.org/10.1136/thx.2004.037283

68. Lasmar L, Camargos P, Champs NS, et al. Adherence rate to inhaled corticosteroids and their impact on asthma control. Allergy 2009;64(5):784-9. http://dx.doi.org/10.1111/j.1398-9995.2008.01877.x

69. Williams LK, Peterson EL, Wells K, et al. Quantifying the proportion of severe asthma exacerbations attributable to inhaled corticosteroid nonadherence. I Allergy Clin Immunol 2011;128(6):1185-91 e2.

70. Watson JP, Cowen P, Lewis RA. The relationship between asthma admission rates, routes of admission, and socioeconomic deprivation. Eur Respir J 1996;9(10):208793. http://dx.doi.org/10.1183/09031936.96.09102087

71. Bacon SL, Bouchard A, Loucks EB, Lavoie KL. Individual-level socioeconomic status is associated with worse asthma morbidity in patients with asthma. Respir Res 2009;10:125. http://dx.doi.org/10.1186/1465-9921-10-125

72. ten Brinke A, Sterk PJ, Masclee AA, et al. Risk factors of frequent exacerbations in difficult-to-treat asthma. Eur Respir J 2005;26(5):812-18. http://dx.doi.org/10.1183/09031936.05.00037905

73. Bousquet J, Gaugris S, Kocevar VS, et al. Increased risk of asthma attacks and emergency visits among asthma patients with allergic rhinitis: a subgroup analysis of the investigation of montelukast as a partner agent for complementary therapy [corrected]. Clin Exp Allergy 2005;35(6):723-7. http://dx.doi.org/10.1111/j.1365-2222.2005.02251.x

74. Black PN, Udy AA, Brodie SM. Sensitivity to fungal allergens is a risk factor for lifethreatening asthma. Allergy 2000;55(5):501-04. http://dx.doi.org/10.1034/j.1398-9995.2000.00293.x

75. Haselkorn T, Fish JE, Chipps BE, Miller DP, Chen H, Weiss ST. Effect of weight change on asthma-related health outcomes in patients with severe or difficult-to-treat asthma. Respir Med 2009; 103(2):274-83. http://dx.doi.org/10.1016/j.rmed.2008.08.010

76. Kattan M, Kumar R, Bloomberg GR, et al. Asthma control, adiposity, and adipokines among inner-city adolescents. J Allergy Clin Immunol 2010;125(3):584-92. http://dx.doi.org/10.1016/j.jaci.2010.01.053

77. Anderson GP. Endotyping asthma: new insights into key pathogenic mechanisms in a complex, heterogeneous disease. Lancet 2008;372(9643):1107-19. http://dx.doi.org/10.1016/S0140-6736(08)61452-X

78. Postma D, Anzueto A, Calverley $P$, et al. A new perspective on optimal care for patients with COPD. Prim Care Respir J 2011;20(2):205-09. http://dx.doi.org/10.4104/pcri.2011.00041

79. Bafadhel M, McKenna S, Terry S, et al. Blood eosinophils to direct corticosteroid treatment of exacerbations of chronic obstructive pulmonary disease: a randomized placebo-controlled trial. Am J Respir Crit Care Med 2012;186(1):48-55. http://dx.doi.org/10.1164/rccm.201108-15530C

80. Bafadhel M, McKenna S, Terry S, et al. Acute exacerbations of chronic obstructive pulmonary disease: identification of biologic clusters and their biomarkers. Am J
Respir Crit Care Med 2011;184(6):662-71.

http://dx.doi.org/10.1164/rccm.201104-05970C

81. Pavord ID, Wardlaw AJ. The A to E of airway disease. Clin Exp Allergy 2010;40(1):627. http://dx.doi.org/10.1111/j.1365-2222.2009.03410.x

82. Gonem S, Raj V, Wardlaw AJ, Pavord ID, Green R, Siddiqui S. Phenotyping airways disease: an A to E approach. Clin Exp Allergy 2011;42(12):1664-83. http://dx.doi.org/10.1111/j.1365-2222.2012.04008.x

83. Moore WC, Meyers DA, Wenzel SE, et al. Identification of asthma phenotypes using cluster analysis in the Severe Asthma Research Program. Am J Respir Crit Care Med 2010;181(4):315-23. http://dx.doi.org/10.1164/rccm.200906-08960C

84. Green RH, Brightling CE, McKenna $\mathrm{S}$, et al. Asthma exacerbations and sputum eosinophil counts: a randomised controlled trial. Lancet 2002;360(9347):1715-21. http://dx.doi.org/10.1016/S0140-6736(02)11679-5

85. Carver CS, Scheier MF, Weintraub JK. Assessing coping strategies: a theoretically based approach. J Pers Soc Psychol 1989;56(2):267-83

http://dx.doi.org/10.1037/0022-3514.56.2.267

86. Yellowlees PM, Ruffin RE. Psychological defenses and coping styles in patients following a life-threatening attack of asthma. Chest 1989;95(6):1298-303.

87. Campbell DA, Yellowlees PM, McLennan G, et al. Psychiatric and medical features of near fatal asthma. Thorax 1995;50(3):254-9.

http://dx.doi.org/10.1136/thx.50.3.254

88. Nazarian D, Smyth JM, Sliwinski MJ. A naturalistic study of ambulatory asthma severity and reported avoidant coping styles. Chronic IIIn 2006;2(1):51-8.

89. Cooke L, Myers L, Derakshan N. Lung function, adherence and denial in asthma patients who exhibit a repressive coping style. Psychol Health Med 2003;8(1):35-44. http://dx.doi.org/10.1080/1354850021000059241

90. British Thoracic Society/Scottish Intercollegiate Guidelines Network. British guideline on the management of asthma. Thorax 2008;63(Suppl 4):iv1-121. http://dx.doi.org/10.1136/thx.2008.097741

91. Seddon P, Bara A, Ducharme FM, Lasserson TJ. Oral xanthines as maintenance treatment for asthma in children. Cochrane Database Syst Rev 2006 (1):CD002885.

92. Pauwels RA, Lofdahl CG, Postma DS, et al. Effect of inhaled formoterol and budesonide on exacerbations of asthma. Formoterol and Corticosteroids Establishing Therapy (FACET) International Study Group. N Engl I Med 1997;337(20):1405-11. http://dx.doi.org/10.1056/NEJM199711133372001

93. Boyle RJ, Pedroletti C, Wickman M, et al. Nocturnal temperature controlled laminar airflow for treating atopic asthma: a randomised controlled trial. Thorax 2012;67(3):215-21. http://dx.doi.org/10.1136/thoraxjnl-2011-200665

94. Castro $M$, Rubin AS, Laviolette $M$, et al. Effectiveness and safety of bronchial thermoplasty in the treatment of severe asthma: a multicenter, randomized, doubleblind, sham-controlled clinical trial. Am J Respir Crit Care Med 2010;181(2):116-24. http://dx.doi.org/10.1164/rccm.200903-03540C

95. Pavord ID, Korn S, Howarth $\mathrm{P}$, et al. Mepolizumab for severe eosinophilic asthma (DREAM): a multicentre, double-blind, placebo-controlled trial. Lancet 2012;380(9842):651-9. http://dx.doi.org/10.1016/S0140-6736(12)60988-X

96. Flood-Page P, Swenson C, Faiferman I, et al. A study to evaluate safety and efficacy of mepolizumab in patients with moderate persistent asthma. Am J Respir Crit Care Med 2007;176(11):1062-71. http://dx.doi.org/10.1164/rccm.200701-0850C

97. Haldar $P$, Brightling $C E$, Hargadon $B$, et al. Mepolizumab and exacerbations of refractory eosinophilic asthma. N Engl J Med 2009;360(10):973-84. http://dx.doi.org/10.1056/NEJMoa0808991

98. Nair P, Pizzichini MM, Kjarsgaard M, et al. Mepolizumab for prednisone-dependent asthma with sputum eosinophilia. N Engl J Med 2009;360(10):985-93. http://dx.doi.org/10.1056/NEJMoa0805435

99. Hubbard R, Tattersfield A, Smith C, West J, Smeeth L, Fletcher A. Use of inhaled corticosteroids and the risk of fracture. Chest 2006;130(4):1082-8. http://dx.doi.org/10.1378/chest.130.4.1082

100. Chowdhury BA, Dal Pan G. The FDA and safe use of long-acting beta-agonists in the treatment of asthma. N Engl J Med 2010;362(13):1169-71. http://dx.doi.org/10.1056/NEJMp1002074

101. Michele TM, Pinheiro S, lyasu S. The safety of tiotropium: the FDA's conclusions. $N$ Eng/ J Med 2010;363(12):1097-9. http://dx.doi.org/10.1056/NEJMp1008502

102. O'Neill S, Sweeney J, Neill CO, et al. The cost of refractory asthma in the UK: a preliminary analysis. Thorax 2012;67(Suppl 2):A32.

http://dx.doi.org/10.1136/thoraxjnl-2012-202678.070

103. Hawkins G, McMahon AD, Twaddle S, Wood SF, Ford I, Thomson NC. Stepping 
down inhaled corticosteroids in asthma: randomised controlled trial. BMJ 2003;326(7399):1115. http://dx.doi.org/10.1136/bmj.326.7399.1115

104. Bodzenta-Lukaszyk A, Dymek A, McAulay K, Mansikka H. Fluticasone/formoterol combination therapy is as effective as fluticasone/salmeterol in the treatment of asthma, but has a more rapid onset of action: an open-label, randomized study. BMC Pulm Med 2011;11:28. http://dx.doi.org/10.1186/1471-2466-11-28

105. Sugihara N, Kanada S, Haida M, et al. 24-h bronchodilator efficacy of single doses of indacaterol in Japanese patients with asthma: a comparison with placebo and salmeterol. Respir Med 2010;104(11):1629-37. http://dx.doi.org/10.1016/j.rmed.2010.06.011

106. Feldman G, Walker RR, Brooks J, Mehta R, Crater G. 28-Day safety and tolerability of umeclidinium in combination with vilanterol in COPD: a randomized placebocontrolled trial. Pulm Pharmacol Ther 2012;25(6):465-71.

http://dx.doi.org/10.1016/j.pupt.2012.08.007

107. Hanania NA, Feldman G, Zachgo W, et al. The efficacy and safety of the novel longacting beta2 agonist vilanterol in patients with COPD: a randomized placebocontrolled trial. Chest 2012;142(1):119-27. http://dx.doi.org/10.1378/chest.11-2231

108. Walsh S, Hagan T, Gamsu D. Rescuer and rescued: applying a cognitive analytic perspective to explore the 'mis-management' of asthma. $\mathrm{Br} J$ Med Psychol 2000;73(Pt 2):151-68. http://dx.doi.org/10.1348/000711200160390

109. Blakey JD, Obediat M, Pogson Z, Sayers I, Hall IP. A simple asthma severity score predicts exacerbations. American Thoracic Society; Denver, Colorado, 2011. p. A2248

110. Asthma UK. The Triple A test 2012. Available from: http://www.asthma.org.uk/getinvolved/our-campaigns/the-triple-a-avoid-asthma-attacks-campaign/.
111. Blakey J, Woulnough K, Walker S, et al. The asthma UK risk assessment project (AURA) phase two: systematic review of risk factors for asthma exacerbation. York: NIHR, 2012. Available from: http://www.crd.york.ac.uk/PROSPERO/ display_record.asp?ID=CRD42012002338

112. Giraud V, Roche N. Misuse of corticosteroid metered-dose inhaler is associated with decreased asthma stability. Eur Respir J 2002;19(2):246-51. http://dx.doi.org/10.1183/09031936.02.00218402

113. Spiegelhalter $D$, Pearson M, Short I. Visualizing uncertainty about the future. Science 2011;333(6048):1393-400. http://dx.doi.org/10.1126/science.1191181

114. Horne R, Price D, Cleland J, et al. Can asthma control be improved by understanding the patient's perspective? BMC Pulm Med 2007;7:8. http://dx.doi.org/10.1186/1471-2466-7-8

115. Krones T, Keller H, Sadowski E. Absolute cardiovascular disease risk and shared decision making in primary care: a randomized controlled trial. Ann Fam Med 2008;6(3):218-27. http://dx.doi.org/10.1370/afm.854

116. Parkes G, Greenhalgh T, Griffin M, Dent R. Effect on smoking quit rate of telling patients their lung age: the Step2quit randomised controlled trial. BMJ 2008;336:598. http://dx.doi.org/10.1136/bmj.39503.582396.25

117. Gamble J, Stevenson M, Heaney LG. A study of a multi-level intervention to improve non-adherence in difficult to control asthma. Respir Med 2011;105(9):1308-15. http://dx.doi.org/10.1016/j.rmed.2011.03.019

118. Schmaling KB, Blume A, Afari N. A randomized controlled pilot study of motivational interviewing to change attitudes about adherence to medications for asthma. J Clin Psychol Med Settings 2001;8(3):167-72.

http://dx.doi.org/10.1023/A:1011365519345

\section{Available online at http://www.thepcrj.org}

